\title{
Effect of camel chymosin on the texture, functionality, and sensory properties of low-moisture, part-skim Mozzarella cheese
}

\author{
A. C. Moynihan, ${ }^{*}$ S. Govindasamy-Lucey, $\dagger^{1}$ J. J. Jaeggi, $\uparrow$ M. E. Johnson, $\dagger$ J. A. Lucey, $† \ddagger$ \\ and P. L. H. McSweeney* \\ ${ }^{*}$ School of Food and Nutritional Sciences, University College Cork, Cork, Ireland \\ †Wisconsin Center for Dairy Research, and \\ łDepartment of Food Science, University of Wisconsin-Madison, 1605 Linden Drive, Madison 53706
}

\section{ABSTRACT}

The objective of this study was to compare the effect of coagulant (bovine calf chymosin, BCC, or camel chymosin, CC), on the functional and sensory properties and performance shelf-life of low-moisture, part-skim (LMPS) Mozzarella. Both chymosins were used at 2 levels [0.05 and 0.037 international milk clotting units $(\mathrm{IMCU}) / \mathrm{mL}$ ], and clotting temperature was varied to achieve similar gelation times for each treatment (as this also affects cheese properties). Functionality was assessed at various cheese ages using dynamic lowamplitude oscillatory rheology and performance of baked cheese on pizza. Cheese composition was not significantly different between treatments. The level of total calcium or insoluble (INSOL) calcium did not differ significantly among the cheeses initially or during ripening. Proteolysis in cheese made with BCC was higher than in cheeses made with CC. At $84 \mathrm{~d}$ of ripening, maximum loss tangent values were not significantly different in the cheeses, suggesting that these cheeses had similar melt characteristics. After 14 $\mathrm{d}$ of cheese ripening, the crossover temperature (loss tangent $=1$ or melting temperature) was higher when $\mathrm{CC}$ was used as coagulant. This was due to lower proteolysis in the $\mathrm{CC}$ cheeses compared with those made with $\mathrm{BCC}$ because the $\mathrm{pH}$ and INSOL calcium levels were similar in all cheeses. Cheeses made with CC maintained higher hardness values over $84 \mathrm{~d}$ of ripening compared with BCC and maintained higher sensory firmness values and adhesiveness of mass scores during ripening. When melted on pizzas, cheese made with CC had lower blister quantity and the cheeses were firmer and chewier. Because the 2 types of cheeses had similar moisture contents, $\mathrm{pH}$ values, and INSOL Ca levels, differences in proteolysis were responsible for the firmer and chewier texture of CC cheeses. When cheese

Received May 30, 2013.

Accepted September 30, 2013.

${ }^{1}$ Corresponding author: rani@cdr.wisc.edu performance on baked pizza was analyzed, properties such as blister quantity, strand thickness, hardness, and chewiness were maintained for a longer ripening time than cheeses made with $\mathrm{BCC}$, indicating that use of CC could help to extend the performance shelf-life of LMPS Mozzarella.

Key words: camel chymosin, low-moisture part-skim Mozzarella cheese, proteolysis, performance shelf-life

\section{INTRODUCTION}

The melt and stretch performance of any cheese when baked on pizza is determined by cheese composition, $\mathrm{pH}$ history (especially extent of acidification at coagulant addition), insoluble (INSOL) colloidal calcium phosphate content, and the amount of intact casein (Johnson and Lucey, 2006). As cheese ages, residual proteolytic activity of the coagulant can quickly hydrolyze sufficient casein to greatly increase flowability and decrease the stretch of cheese, both to the extent that bake performance may be negatively affected. During refrigerated storage, low-moisture, part-skim (LMPS) Mozzarella loses its desired firmness and chewiness. The ability to conveniently slice or shred the cheese for use on pizza is diminished. Low-moisture, part-skim Mozzarella cheese also tends to become sticky, clump, and cling to mechanical blades. Proteolysis and aging, therefore, limit the window in which industrial convertors can slice or shred the cheese but can also limit retail and home shelf-life.

The principal proteolytic agent in cheese is the coagulant, and limiting its activity in high moisture cheeses increases the shelf-life, which will help to maintain the desirable characteristics consumers are looking for in those cheeses. Historically, different methods have been used by cheese manufacturers to reduce residual coagulant activity in cheeses; substantially reducing the amount of coagulant used, greatly reducing the storage temperature including freezing the cheese. For pasta filata cheeses, the use of less proteolytic coagulants to greatly increase the water temperature and processing 
time during the pasta filata step have also all been used (Sheehan et al., 2004).

Recently, a coagulant became available that has strong clotting activity but reduced overall proteolytic activity. This enzyme is a fermentation-produced coagulant originally derived from camels and is sold by Chr. Hansen's Laboratory (Milwaukee, WI) as Chymax M. Kappeler et al. (2006) studied fermentation-produced camel chymosin (CC) compared with fermentationproduced bovine calf chymosin (BCC). Average clotting activity on bovine $\kappa$-casein was $70 \%$ greater for $\mathrm{CC}$ compared with BCC but it had lower general proteolytic activity on bovine caseins. Camel chymosin was found to have a 7 -fold higher ratio of clotting activity to general proteolytic activity compared with BCC.

Bansal et al. (2009) used fermentation-produced CC and BCC to manufacture full-fat Cheddar cheese. The level of coagulant was varied to give comparable gel strengths at cutting, which resulted in the use of $30 \%$ less international milk clotting units (IMCU)/mL for CC. Cheese made from BCC exhibited higher primary proteolysis, which was attributed to both the lower usage level of CC added and its lower general proteolytic activity. At the end of ripening, cheese made with $\mathrm{CC}$ had higher hardness and chewiness values than cheese made with BCC. Urea-PAGE analyses also indicated that an important (hydrophobic) bitter peptide, $\beta-\mathrm{CN}(\mathrm{f} 1-189 / 192)$, was not observed in cheeses made with CC (Bansal et al., 2009). This indicates that CC may not be hydrolyzing much of $\beta-\mathrm{CN}$. This has important ramifications for the firmness, and perhaps flow, of cheese when it is heated. Lucey et al. (2003) described the flow and stretch of cheese when heated as being influenced by 3 competing factors: charge repulsion or attraction, hydrophobic attraction, and degree of intact casein or INSOL Ca levels. If there is no charge repulsion or too much attraction (such as very low $\mathrm{pH}$ cheese $<4.95$ ) or too much INSOL Ca crosslinking (such as high pH cheese $>6.2$ ), then there is no flow. However, regardless of the degree of charge repulsion or hydrophobic attraction, if the amount of intact casein is reduced sufficiently through proteolysis, the cheese will flow when heated and there will be a loss in stretch length (Lucey et al., 2003).

Govindasamy-Lucey et al. (2010) made low-fat Cheddar cheese with starter cultures characterized by their known propensity to cause bitterness and used $20 \%$ less $\mathrm{CC}$ compared with BCC. They found that, during ripening, low-fat Cheddar cheese made with CC produced lower levels of soluble $\mathrm{N}$ and had higher hardness and chewiness values. For cheeses made with $\mathrm{CC}$ compared with cheese made with BCC, the loss tangent (LT) and degree of flow values (indices of cheese meltability) were lower at 1 and 3 mo of ripening.
The level of residual coagulant activity in Mozzarella cheese depends on the temperature of stretching; proteolysis progressively decreases with higher stretching temperatures (Kindstedt et al., 2004). Kindstedt et al. (1995) varied the level of BCC used in Mozzarella cheese from 60 to $100 \%$ (of the amount normally used). Using lower levels of BCC significantly reduced free oil formation and rate of proteolysis, although no significant effects were observed on the hardness (as determined by texture profile analysis) of the unmelted cheese or the meltability of the cheese (Kindstedt et al., 1995). The authors in that study used a higher $\mathrm{pH}$ at draining (6.4), which may have resulted in a lesser amount of $\mathrm{BCC}$ being retained in cheese, resulting in generally lowered proteolysis and thus no significant differences in the functional characteristics of the cheeses. Sheehan et al. (2004) studied the effect of 3 types of coagulants: BCC, Rhizomucor miehei rennet, and Rhizomucor pusillus rennet, on the functionality of reduced-fat Mozzarella. The composition of all cheeses produced from these coagulants was similar. Coagulant type also did not influence the functional properties (firmness and flowability) of Mozzarella cheese, although the level of primary proteolysis was affected by the coagulant type. The authors suggested that these differences in primary proteolysis by using the different coagulants were probably not sufficiently large enough to induce significant increase in heat-induced flowability. However, in directly acidified Mozzarella, the type of coagulant used did affect the functional properties of the cheese, such as melt and stretch (Oberg et al., 1992); cheeses made with BCC had more melt but less stretch, which was consistent with greater proteolysis of $\alpha-\mathrm{CN}$ by $\mathrm{BCC}$ compared with the other milk clotting enzymes that were studied. In contrast, porcine pepsin had the most stretch and least increase in melt, which was attributed to porcine pepsin preferentially degrading $\beta-\mathrm{CN}$ over $\alpha-\mathrm{CN}$, causing less weakening of the protein network. It thus appears that coagulant type and usage level are both parameters that can affect some of the properties of Mozzarella cheese.

Optimum functional properties of LMPS Mozzarella are usually observed between 2 and 6 wk for cheeses that are stored refrigerated. Desirable cheese properties include retaining sufficient firmness to allow machinability, sufficient melt, and stretchability (Alvarez, 1986), although the exact specific functionality required varies according to the needs of the end-user. Several reports have attributed the softening of Mozzarella cheese during refrigerated storage to proteolysis (Creamer, 1976; De Jong, 1976; Farkye et al., 1991; Oberg et al., 1991a,b; Tunick et al., 1993). Beyond 6 wk of refrigerated storage, excessive proteolysis can be a contributing factor to decreased machinability (Chen et 
al., 2009). It is believed that the use of CC may extend the functional shelf life of LMPS Mozzarella cheese compared with cheese made with BCC because of the lower proteolytic activity of CC. However, it is unclear if the lower proteolytic activity previously observed (Bansal et al., 2009; Govindasamy Lucey et al., 2010; Grant, 2011) in cheeses made with CC was caused by lower general proteolytic activity on bovine caseins or was due to the lower enzyme addition leading to lower level of primary proteolysis. The objective of this study was to compare functional and sensory properties and shelf-life performance of LMPS Mozzarella cheese manufactured with different coagulants (BCC and CC). We wanted to compare the properties of cheeses made with similar levels of both BCC and CC. However, clotting time will be faster in the milks renneted with the same amount of $\mathrm{CC}$ as that of BCC because of its greater clotting activity (Bansal et al., 2009). Thus, we wanted to experimentally vary the level (IMCU) of both coagulants from a high (0.05 IMCU) to a low (0.037 IMCU) level of coagulant addition. Because of the different clotting activities between $\mathrm{CC}$ and BCC, we adjusted the clotting temperature to obtain similar gelation times in all treatments. Therefore, the objective of this current study was to compare LMPS Mozzarella cheese manufactured with different coagulants (BCC and CC) and 2 coagulant levels (0.05 and 0.037 $\mathrm{IMCU} / \mathrm{mL}$ ) when the cheese compositions were similar.

\section{MATERIALS AND METHODS}

\section{Selection of Coagulant Levels for Cheesemaking}

The 2 coagulants used in this study were fermentation-produced BCC (Chy-Max Extra, $630 \mathrm{IMCU} / \mathrm{mL}$; Chr. Hansen Inc., Milwaukee, WI) and CC (Chy-Max M, 1,000 IMCU/mL; Chr. Hansen Inc.).

To achieve similar gelation times, we needed to adjust the renneting temperatures for $\mathrm{BCC}$ and $\mathrm{CC}$ when using the 2 coagulant levels (0.037 and $0.05 \mathrm{IMCU} /$ $\mathrm{mL}$ ). We performed preliminary gelation trials using dynamic oscillatory rheology as described by Govindasamy-Lucey et al. (2004). The time point at which the storage modulus $\left(\mathbf{G}^{\prime}\right)$ was $>1 \mathrm{~Pa}$ was defined as the gelation time. A rheometer (MCR 301, Anton Paar $\mathrm{GmbH}$, Österreich, Austria) was used to determine the rheological characteristics of the gels during renneting using an oscillation test that was performed at $1 \%$ strain and a frequency of $0.1 \mathrm{~Hz}$. A concentric cylinder (CC27/T200/SS, Anton Paar GmbH) measuring geometry was used. Reconstituted skim milk (10\%, wt/vol) was prepared using low-heat skim milk powder (Dairy America, Fresno, CA) containing $0.01 \%$ (wt/wt) $\mathrm{CaCl}_{2}$ to assess rennet coagulation properties. Reconstituted milks were held at the appropriate gelation temperature for $30 \mathrm{~min}$ in a water bath, and $10 \mu \mathrm{L}$ of the appropriately diluted chymosin (BCC or $\mathrm{CC}$ ) was added to the milk and placed in the cup of the rheometer. To prevent surface dehydration, a layer of vegetable oil was put on the surface of the milk. The oscillation test was started 2 min after the addition of the coagulant and $\mathrm{G}^{\prime}$ values were recorded at 1-min intervals. Rennet coagulation temperature was varied to give similar gelation times for each treatment. For the low level of BCC, $0.006 \%$ (wt/wt) $\mathrm{CaCl}_{2}$ was added to the milk to obtain a gelation time similar to the other treatments.

Based on these preliminary experiments, we obtained similar gelation times $(20.1 \pm 0.6 \mathrm{~min} ; P>0.05)$ in all treatments. For $\mathrm{BCC}$ at the $0.05 \mathrm{IMCU} / \mathrm{mL}$ level, a renneting temperature of $33.3^{\circ} \mathrm{C}$ was used. At the 0.037 $\mathrm{IMCU} / \mathrm{mL}$ level for $\mathrm{BCC}$, a renneting temperature of $36^{\circ} \mathrm{C}$ was used but $0.006 \% \mathrm{CaCl}_{2}$ (wt/wt) also had to be added to the milk.

\section{Cheese Manufacture}

Four vats of LMPS Mozzarella cheese were manufactured in the dairy plant at the University of WisconsinMadison in triplicate (on 3 separate days). The milk clotting conditions (selected based on the preliminary coagulation experiments as described above) and type of coagulant used was varied for each vat; 2 vats each were manufactured for $\mathrm{BCC}$ and $\mathrm{CC}$ coagulated cheeses using high $(0.05 \mathrm{IMCU} / \mathrm{mL})$ and low $(0.037 \mathrm{IMCU} / \mathrm{mL})$ levels of the enzymes. Control cheese was manufactured with high level (0.05 IMCU/mL, BCC (HBCC) using a renneting temperature of $33.3^{\circ} \mathrm{C}$. Cheese made with low level of BCC (0.037 IMCU/mL; LBCC) required a higher renneting temperature of $36.0^{\circ} \mathrm{C}$. For this vat, we also added $\mathrm{CaCl}_{2}$ to give a final concentration of $0.006 \% \mathrm{CaCl}_{2}$ (wt/wt) so that its gelation time would be similar to that of the other treatments. Two vats of cheese were manufactured with CC; low (0.037 IMCU/ $\mathrm{mL}) \mathrm{CC}$ levels (LCC) that had a renneting temperature of $33.3^{\circ} \mathrm{C}$ (similar to that of the $\mathrm{HBCC}$ ) and the high $\mathrm{CC}$ level $(0.05 \mathrm{IMCU} / \mathrm{mL}, \mathbf{H C C})$ that needed a lower renneting temperature of $31.5^{\circ} \mathrm{C}$.

Before cheesemaking, $272 \mathrm{~kg}$ of milk (2.3\% fat, CN:fat ratio of 1.1) was pasteurized at $72^{\circ} \mathrm{C}$ for $19 \mathrm{~s}$ and cooled to the appropriate renneting temperature for each vat as described above. A direct-vat-set thermophilic culture comprising a Streptococcus thermophilus and Lactobacillus helveticus blend (Tempo 303; Cargill Texturizing Solutions, Waukesha, WI) was added to each of the vats at a level of $90 \mathrm{~g} / 100 \mathrm{~kg}$ of milk. After ripening for $60 \mathrm{~min}, \mathrm{BCC}$ or $\mathrm{CC}$ was added at the high $(0.05$ $\mathrm{IMCU} / \mathrm{mL})$ or low $(0.037 \mathrm{IMCU} / \mathrm{mL})$ treatment level for each type of enzyme. 
The coagula were cut at similar firmness as subjectively evaluated by an experienced licensed Wisconsin cheesemaker. The $\mathrm{pH}$ at cutting for all cheeses was 6.5. All coagula were cut with $1.9-\mathrm{cm}$ knives. The temperature of all vats was increased to $41^{\circ} \mathrm{C}$ over a 30-min period. Each vat was cooked until the $\mathrm{pH}$ reached 5.90; agitation was then stopped, curd was trenched, and the whey was drained. At $\mathrm{pH} 5.25$, all cheeses were milled and presalted at a level of $0.26 \%$ (wt/wt, based on weight of cheesemilk) and stretched in a cooker (Supreme Filata Mixer, Stainless Steel Fabricating Inc., Columbus, WI) for about $7 \mathrm{~min}$. The curd temperature was about $54^{\circ} \mathrm{C}$. After stretching, the hot curd was placed in 2.3-kg blocks, which were kept in cold water for $30 \mathrm{~min}$ and then brined (in $25 \%$ salt brine) for 120 min at approximately $4^{\circ} \mathrm{C}$. The brine-salted cheeses were vacuum-packed and stored at $3^{\circ} \mathrm{C}$ for $84 \mathrm{~d}$. Analysis was performed at d 1, 14, 28, 42, 56, and 84 .

\section{Compositional Analysis}

Compositional analysis was carried out at d 14. At the time of sampling, a quarter of the block was cut off and half of this quarter was completely ground and used for analysis. Cheese was analyzed for moisture by oven drying (Marshall, 1992), fat by Mojonnier (AOAC International, 2000), protein by Kjeldahl (AOAC International, 2000), and salt by chloride electrode method (MK II Chloride analyzer 926, Nelson \& Jameson Inc., Marshfield, WI; Johnson and Olson 1985). Total Ca was measured for milk, rennet whey, and cheese at d 14 using inductively coupled plasma emission spectroscopy (Park, 2000). Cheese pH, proteolysis, and INSOL $\mathrm{Ca}$ content were measured during ripening. The $\mathrm{pH}$ was monitored by grinding $10 \mathrm{~g}$ of cheese with $10 \mathrm{~mL}$ of distilled water and measuring the $\mathrm{pH}$ of the slurry using a pH meter (Accumet AB15 Plus, Fisher Scientific, Singapore; Madkor et al., 1987). Insoluble Ca content was measured by acid-base titration method (Hassan et al., 2004). Proteolysis was determined by $\mathrm{pH} 4$.6-soluble N (Kuchroo and Fox, 1982).

\section{Dynamic Small-Amplitude Oscillatory Rheology of Cheese}

The rheological properties of the cheeses were studied using a Paar Physica Universal Dynamic Spectrometer (UDS 200 Physica Messtechnik, Stuttgart, Germany) as described by Govindasamy-Lucey et al. (2005). Cheeses were heated from 5 to $85^{\circ} \mathrm{C}$ at $1^{\circ} \mathrm{C} / \mathrm{min}$. A 50$\mathrm{mm}$ serrated parallel plate was used and the cheese was subjected to a strain of $0.5 \%$ at a frequency of $0.08 \mathrm{~Hz}$. The parameters measured during heating of the cheese were $G^{\prime}$, loss modulus $\left(G^{\prime \prime}\right)$, and $\operatorname{LT}\left(G^{\prime \prime} / G^{\prime}\right)$. The temperature at which LT was equal to 1 (i.e., where $\mathrm{G}^{\prime}=\mathrm{G}^{\prime \prime}$ ) was also calculated because this indicates the transition from a solid to a liquid-like system (i.e., a crossover point). The maximum LT ( $\mathbf{L} \mathbf{T}_{\max }$ ) values were also recorded.

\section{Texture Profile Analysis}

Cheese was cut into cylindrical samples $(16 \mathrm{~mm}$ in diameter, $17.5 \mathrm{~mm}$ high) and stored overnight at $4^{\circ} \mathrm{C}$ before compression. Texture analysis was performed using a Texture Analyzer TA-XT2 (Stable Micro Systems, Godalming, Surrey, UK). Texture profile analysis (TPA) was performed by compressing a sample to $62 \%$ of its original height; hardness was calculated as previously described by Bourne (1978).

\section{Descriptive Sensory Analysis}

A trained (20 h of training) sensory panel consisting of at least 12 panelists used a mixture of sensory Spectrum and quantitative descriptive analysis (Meilgaard et al., 1999) to evaluate the textural and flavor properties of both the unmelted and melted cheese as described by Chen et al. (2009; Table 1). The numerical intensity scale ranged from 0 to 15 with reference points. Each cheese was designated with a random 3 -digit code and assessed in duplicate on 2 separate days. Cheese cubes were tempered at $\sim 12^{\circ} \mathrm{C}$ before assessment for texture and flavor attributes (saltiness and acidity; Table 1). Textural attributes evaluated were firmness and adhesiveness of mass of the cubes (Table 1 ).

Cheeses were mechanically shredded using a food processor (Cuisinart Prep 11 Plus, Madison, WI). A 30.5-cm frozen pizza crust (Arrezzio Thin \& Crisp ParBaked, Sysco Food Services, Baraboo, WI) was thawed and $30 \mathrm{~g}$ of tomato pizza sauce (Contadina Roma-style tomatoes pizza sauce, Metcalfe's Market, Madison, WI) was spread over the crust. Approximately $300 \mathrm{~g}$ of shredded cheese was added to the crust, which was then baked in a forced-air commercial oven (Impinger Ovens, Lincoln Foodservice Products Inc., Ford Wayne, IN) at $260^{\circ} \mathrm{C}$ for $5 \mathrm{~min}$. The surface characteristics evaluated included free oil release, blister color, blister quantity, and skinning. Stretch characteristics of the cheeses were evaluated by determining the strand length and thickness of the stretched cheese (Table 1). Textural properties (i.e., cohesiveness of mass, chewiness, and hardness) of the melted cheese were evaluated after cooling to $63^{\circ} \mathrm{C}$. Photographs of cheeses at the different reference points were available to the panelists. Flavor attributes (acid and salt intensities) of melted cheeses were also assessed at $63^{\circ} \mathrm{C}$. 
Table 1. Definitions of the attributes used by the trained panelists to evaluate the flavor and texture of the unmelted and melted low-moisture, part-skim Mozzarella cheeses using a combination of Spectrum and quantitative descriptive analysis

\begin{tabular}{ll}
$\begin{array}{l}\text { Method of } \\
\text { analysis/attribute }\end{array}$ & Definition and evaluation procedure \\
\hline $\begin{array}{l}\text { Unmelted cheese } \\
\text { Hand firmness }\end{array}$ & $\begin{array}{l}\text { Force required to compress the cheese between } \\
\text { finger and thumb. } \\
\text { Place the cheese cube between thumb and } \\
\text { forefinger. Compress cheese cube; do not fracture. }\end{array}$ \\
& $\begin{array}{l}\text { Degree to which mass sticks to the roof of the } \\
\text { mouth or teeth. Chew cheese sample between } \\
\text { molars } 12 \text { to } 15 \text { times. Evaluate cheese adhesive } \\
\text { properties. }\end{array}$
\end{tabular}

Melted cheese surface characteristics ${ }^{1}$ (evaluated at $96.1^{\circ} \mathrm{C}$ )

Free oil release ${ }^{2}$

Blister color ${ }^{2}$

Blister quantity ${ }^{2}$

Skinning

Stretch characteristics ${ }^{1}$ (evaluated at $90.6^{\circ} \mathrm{C}$ )

Stretch-Strand length

Stretch-Strand

thickness $^{2}$

Texture (evaluated at $62.8^{\circ} \mathrm{C}$ after

heating step) Hardness (first chew)

Chewiness (chewdown characteristics)

Cohesiveness of mass (chewdown characteristics) cheese.

The brown color intensity of the blisters. pizza pie. melted cheese. melted cheese. the height to which the cheese is stretched.

The thickness of the melted cheese strand. pulling strand. Observe the melted cheese strand thickness at 3 inches. If strand does not reach 6

Force required to bite through the sample with molars. molars.

The length of time required to masticate the sample to a state pending swallowing. The longer the time required, the chewier the sample is. Put cheese sample between molars and chew 15 times. Gather to the middle of mouth, evaluate
References used, preparation instructions, and anchor points (0-15)

Green-colored Thera-Putty (\#5075, Sammon Preston) $=4.5$ Blue-colored Thera-Putty (\#5077, Sammon Preston) $=7.0$ Flesh-colored Thera-Putty (Graham-Field Inc.) $=9.5$

Gray eraser (Primacolor Kneaded Rubber) $=12.0$

White eraser (School Select White) $=15.0$

Polenta $($ Food Merchants Brand $)=0.0$

Quince paste (La Costena Brand) $=2.5$

Rice, converted (Minute Rice Brand) $=3.5$

Mashed potatoes (Hungry Jack Brand) $=7.5$.

Prepared by boiling $2 / 3$ cup water, $1 / 4$ cup milk, 1 tablespoon butter; remove from heat, add 1 cup of dried potato flakes.

Brownies (Betty Crocker Dark Chocolate Fudge Brownie Mix; baked using the recipe on the box $)=10.0$

American Pasteurized Process Cheese Food, Singles (Kraft

Foods) $=14.0$

The amount of free oil on the surface of the melted

The amount of blisters on the melted surface of the

The thickness and toughness of the surface of the

Stretch the cheese. Insert 1 tine of fork $1 \mathrm{~cm}$ into

Pull cheese at a controlled constant rate. Measure

Insert 1 tine of fork $1 \mathrm{~cm}$ into melted cheese. Pull up at a controlled constant rate to 6 inches. Stop inches, please note response as NA (not applicable).

None to extreme

No brown color to all dark brown color

None to complete coverage

None to extreme

Height of the stretch was measured in inches

Reference images used

Fold the cheese into $1 / 4$ with inside out, bite with

Spam (Hormel Brand) $=2.0$

Beef frankfurters (Best's Kosher Brand) $=5.0$

Chewy caramel (Kraft Classic Caramels Traditional $)=7.0$

Almond (Blue Diamond Brand) $=12.0$

Li-Corice (Starburst Brand) $=15.0$

Pound cake (Sara Lee All Butter Pound Cake) $=1.0$

Beef frankfurters (Best's Kosher Brand) $=4.0$

Fig Newtons (Nabisco Brand, Kraft Foods) $=7.0$

White bread (Wonder Brand) $=9.0$

Chewy caramel (Kraft Classic Caramels Traditional $)=12.0$

Chewing gum (Wrigley's Doublemint) $=15.0$

Degree to which sample holds together in a mass. cohesiveness of mass.
Polenta $($ Food Merchants Brand $)=0.0$

Carrots (Metcalfe's Sentry Foods) $=1.0$

Beef frankfurter (Best's Kosher Brand) = 4.5

Wheaties toasted whole wheat flakes (General Mills) $=7.5$

Fig Newtons (Nabisco Brand, Kraft Foods) $=11.0$

White bread (Wonder Brand) $=14.0$ 
Table 1 (Continued). Definitions of the attributes used by the trained panelists to evaluate the flavor and texture of the unmelted and melted low-moisture, part-skim Mozzarella cheeses using a combination of Spectrum and quantitative descriptive analysis

\begin{tabular}{lll}
\hline $\begin{array}{l}\text { Method of } \\
\text { analysis/attribute }\end{array}$ & Definition and evaluation procedure & $\begin{array}{l}\text { References used, preparation instructions, } \\
\text { and anchor points }(0-15)\end{array}$ \\
\hline $\begin{array}{l}\text { Flavor }{ }^{1} \text { (evaluated at } \\
62.8^{\circ} \mathrm{C} \text { after }\end{array}$ & \\
$\begin{array}{l}\text { heating step) } \\
\text { Acid }\end{array}$ & Basic taste sensation elicited by acids & $\begin{array}{l}\text { None to pronounced } \\
\text { Salt }\end{array}$ \\
\hline
\end{tabular}

${ }^{1}$ Attributes were evaluated using quantitative descriptive analysis (Meilgaard et al., 1999), adapted from Chen et al. (2009).
${ }^{2}$ The attributes were evaluated using reference images as described by Chen et al. (2009).

\section{Experimental Design and Statistical Analysis}

Four treatments (coagulant type and levels; HBCC, LBCC, HCC, LCC) were used to manufacture LMPS Mozzarella, in triplicate; each cheesemaking trial was performed on 3 different days. A $4 \times 3$ completely randomized block design that incorporated all 4 treatments and 3 trial days was used for analysis of the response variables relating to cheese composition. Analysis of variance was carried out using the PROC GLM procedure of SAS (version 9.1; SAS Institute, 2002-2003). Scheffé's multiple-comparison test was used to evaluate differences in the treatments at a significance level of $P$ $<0.05$ for cheese composition and coagulation properties of milk.

A split-plot design was used to monitor the effects of treatment (HBCC, LBCC, HCC, LCC) and ripening time and their interactions on $\mathrm{pH}$, INSOL calcium, proteolysis, and functional, textural, and sensory properties. In the whole-plot factor, treatment was analyzed as a discontinuous variable and cheesemaking day was blocked. For the subplot factor, age and age $\times$ treatment were treated as variables. The interactive term treatment $\times$ day of cheesemaking was treated as the error term for the treatment effect. The ANOVA for the split-plot design was carried out using PROC GLM of SAS. Fisher's least significant difference test was carried out to evaluate differences in the treatment means at a significance level of $P<0.05$.

\section{RESULTS AND DISCUSSION}

\section{Cheese Composition, $\mathrm{pH}$, and Level of Insoluble Calcium}

In preliminary studies, when the same manufacturing protocol was used to manufacture all the cheeses, the

Table 2. Composition (14 d) and pH values ( 1 and 14) of low-moisture, part-skim Mozzarella cheese made using high calf (HBCC), low calf (LBCC), high camel (HCC), and low camel (LCC) chymosin treatments (n $=3)$

\begin{tabular}{|c|c|c|c|c|c|c|}
\hline \multirow[b]{2}{*}{ Item } & \multicolumn{4}{|c|}{ Treatment $^{1}$} & \multirow[b]{2}{*}{ SEM } & \multirow[b]{2}{*}{$P$-value ${ }^{2}$} \\
\hline & $\mathrm{HBCC}$ & $\mathrm{LBCC}$ & $\mathrm{HCC}$ & $\mathrm{LCC}$ & & \\
\hline Moisture (\%) & $47.31^{\mathrm{a}}$ & $47.84^{\mathrm{a}}$ & $47.50^{\mathrm{a}}$ & $47.92^{\mathrm{a}}$ & 0.193 & $\mathrm{NS}^{7}$ \\
\hline Fat $(\%)$ & $21.85^{\mathrm{a}}$ & $21.55^{\mathrm{a}}$ & $22.16^{\mathrm{a}}$ & $21.75^{\mathrm{a}}$ & 0.244 & $<0.05$ \\
\hline Salt $(\%)$ & $1.61^{\mathrm{a}}$ & $1.46^{\mathrm{a}}$ & $1.59^{\mathrm{a}}$ & $1.62^{\mathrm{a}}$ & 0.039 & NS \\
\hline Protein $^{3}(\%)$ & $25.41^{\mathrm{a}}$ & $25.77^{\mathrm{a}}$ & $25.43^{\mathrm{a}}$ & $24.95^{\mathrm{a}}$ & 0.163 & $<0.01$ \\
\hline $\operatorname{MNFS}^{4}(\%)$ & $60.54^{\mathrm{a}}$ & $60.99^{\mathrm{a}}$ & $61.02^{\mathrm{a}}$ & $61.24^{\mathrm{a}}$ & 0.340 & NS \\
\hline $\mathrm{FDM}^{5}(\%)$ & $41.46^{\mathrm{a}}$ & $41.31^{\mathrm{a}}$ & $42.20^{\mathrm{a}}$ & $41.77^{\mathrm{a}}$ & 0.519 & $<0.05$ \\
\hline $\mathrm{S} / \mathrm{M}^{6}(\%)$ & $3.40^{\mathrm{a}}$ & $3.05^{\mathrm{a}}$ & $3.35^{\mathrm{a}}$ & $3.38^{\mathrm{a}}$ & 0.081 & NS \\
\hline Total calcium $(\mathrm{mg} / 100 \mathrm{~g})$ & $601^{\mathrm{a}}$ & $598^{\mathrm{a}}$ & $650^{\mathrm{a}}$ & $658^{\mathrm{a}}$ & 15.4 & NS \\
\hline $\mathrm{pH}$ at $1 \mathrm{~d}$ & $5.25^{\mathrm{a}}$ & $5.26^{\mathrm{ab}}$ & $5.30^{\mathrm{b}}$ & $5.26^{\mathrm{ab}}$ & 0.002 & $<0.05$ \\
\hline $\mathrm{pH}$ at $14 \mathrm{~d}$ & $5.28^{\mathrm{b}}$ & $5.30^{\mathrm{b}}$ & $5.34^{\mathrm{a}}$ & $5.31^{\mathrm{b}}$ & 0.001 & $<0.01$ \\
\hline
\end{tabular}

$\overline{\mathrm{a}, \mathrm{b}}$ Means within the same row not sharing a common superscript differ $(P<0.05)$.

${ }^{1}$ Means of the 4 main treatments (coagulant type and levels; HBCC, LBCC, HCC, LCC) were analyzed using the ANOVA of PROC GLM procedure of SAS. Scheffe's multiple-comparison test was used to evaluate differences in the treatments at a significance level of $P<0.05$.

${ }^{2}$ The $P$-value was for the full statistical model, which includes both the effects of treatment and the cheesemaking day.

${ }^{3}$ Total $\% \mathrm{~N} \times 6.38$.

${ }^{4}$ Moisture in the nonfat substance of the cheese.

${ }^{4}$ Fat content on a dry weight basis.

${ }^{6}$ Salt in the moisture phase of the cheese.

${ }^{7}$ Nonsignificant: F test for full statistical model (both treatment and cheesemaking day) $P>0.05$. 
Table 3. Mean squares and probabilities (in parentheses), and $\mathrm{R}^{2}$ values for proteolysis, insoluble calcium, rheological properties, and hardness determined by texture profile analysis (TPA) for low-moisture, part-skim Mozzarella cheese during $84 \mathrm{~d}$ of ripening

\begin{tabular}{|c|c|c|c|c|c|c|c|c|}
\hline Factor $^{1}$ & $\mathrm{df}^{2}$ & $\begin{array}{c}\% \\
\text { Proteolysis }\end{array}$ & df & $\begin{array}{c}\text { INSOL } \\
\mathrm{Ca}^{3}\end{array}$ & df & $\mathrm{LT}_{\max }^{4}$ & $\mathrm{LT}=1^{5}$ & $\begin{array}{c}\text { TPA } \\
\text { hardness }\end{array}$ \\
\hline \multicolumn{9}{|l|}{ Whole-plot } \\
\hline Treatment $(\mathrm{T})$ & 3 & $\begin{array}{c}55.0^{* *} \\
(<0.0001)\end{array}$ & 3 & $\begin{array}{l}54.1 \\
(0.24)\end{array}$ & 3 & $\begin{array}{c}0.469 \\
(0.50)\end{array}$ & $\begin{array}{c}11.9^{* *} \\
(<0.0001)\end{array}$ & $\begin{array}{l}446^{*} \\
(0.01)\end{array}$ \\
\hline Day of cheesemaking (D) & 2 & $\begin{array}{c}1.34^{*} \\
(0.03)\end{array}$ & 2 & $\begin{array}{r}236.3^{*} \\
(0.02)\end{array}$ & 2 & $\begin{array}{c}0.141 \\
(0.15)\end{array}$ & $\begin{array}{c}2.53^{* *} \\
(0.002)\end{array}$ & $\begin{array}{l}786^{* *} \\
(0.004)\end{array}$ \\
\hline \multicolumn{8}{|l|}{ Subplot } & 48.6 \\
\hline Age $(\mathrm{A})$ & 4 & $\begin{array}{l}72.1^{* *} \\
(<0.0001)\end{array}$ & 2 & $\begin{array}{l}732.5^{* *} \\
(<0.0001)\end{array}$ & 3 & $\begin{array}{r}0.305^{* *} \\
(<0.0001)\end{array}$ & $\begin{array}{c}46.4^{* *} \\
(<0.0001)\end{array}$ & $\begin{array}{c}129^{* *} \\
(0.004)\end{array}$ \\
\hline $\mathrm{A} \times \mathrm{T}$ & 12 & $\begin{array}{c}1.86^{* *} \\
(<0.0001)\end{array}$ & 6 & $\begin{array}{c}6.94 \\
(0.89)\end{array}$ & 9 & $\begin{array}{c}0.153^{* *} \\
(0.0006)\end{array}$ & $\begin{array}{c}1.26 \\
(0.15)\end{array}$ & $\begin{array}{l}25.7 \\
(0.36)\end{array}$ \\
\hline Error & 32 & 0.124 & 16 & 19.4 & 24 & 0.293 & 0.746 & 22.0 \\
\hline $\mathrm{R}^{2}$ & & 0.99 & & 0.88 & & 0.81 & 0.91 & 0.88 \\
\hline
\end{tabular}

${ }^{1}$ Split-split plot design with the 4 treatments (coagulant type and levels; HBCC, LBCC, HCC, LCC) were analyzed as a discontinuous variable and cheesemaking day was blocked (a $4 \times 3$ blocked design). Subplot included the effect of aging of cheese $(\mathrm{A})$, and age $\times$ treatment as variables.

${ }^{2}$ Degrees of freedom differed for proteolysis, insoluble calcium, and rheological and textural measurements as the time points for analyses during ripening were different.

${ }^{3}$ Percentage of insoluble calcium as a percentage of total calcium.

${ }^{4}$ Maximum loss tangent values.

${ }^{5}$ Temperature at which loss tangent value $=1$.

${ }^{6} \mathrm{TPA}$ hardness was measured by texture analyzer.

${ }^{*} 0.01<P \leq 0.05 ; * * P \leq 0.01$.

moisture content of the LBCC cheese $(49 \%)$ were much higher than those of the HBCC, HCC, or LCC cheeses ( $\sim 46$ to $47 \%$, data not shown). The cheese manufacturing protocol for the LBCC cheese was then modified (by cutting the coagula at $25 \mathrm{~min}$ after rennet addition compared with $45 \mathrm{~min}$ for other treatments) to decrease the moisture content. Although the cutting time used for the LBCC cheeses was different from the other treatments, the gelation time was similar for all treatments $(20.1 \pm 0.6 \mathrm{~min} ; P>0.05)$.

We observed no significant difference in the composition of all the experimental cheeses (Table 2). The composition of cheeses was similar to that in previous studies on LMPS Mozzarella (Kindstedt et al., 1995). The fat in DM of the cheeses was also within the typical range of values (41-42\%) expected for LMPS Mozzarella.

The $\mathrm{pH}$ values at the critical points during cheese making (rennet addition, cutting, draining, dry salting, mixer molder) were similar between treatments, which resulted in cheeses having similar $(P>0.05)$ total $\mathrm{Ca}$ contents (Table 2). We found no significant difference $(P>0.05)$ in the level of INSOL $\mathrm{Ca}$ in the cheeses (Table 3, Figure 1a). As expected, the level of INSOL $\mathrm{Ca}$ in cheese decreased with age during the first $14 \mathrm{~d}$ of ripening (Figure 1a), in agreement with the trend reported previously for Cheddar cheese (Hassan et al., 2004; Lee et al., 2005). After the first 14 d, little further change in the INSOL Ca content occurred as a function of total Ca in all the cheeses (Figure 1a). Initial changes in functionality and serum retention of cheese can be attributed to the decrease in INSOL Ca but with additional storage the changes in functionality can also be attributed to proteolysis.

Minor differences were observed between the $\mathrm{pH}$ values at 1 and $14 \mathrm{~d}$ (Table 2) but no significant differences $(P>0.05)$ were observed for the $\mathrm{pH}$ values after $14 \mathrm{~d}$ of ripening of any of the treatments (results not shown). The $\mathrm{pH}$ values of the cheeses at $14 \mathrm{~d}$ were higher than at $1 \mathrm{~d}$ because of the buffering effect that occurs as some INSOL Ca becomes soluble (Figure 1a; Hassan et al., 2004).

\section{Proteolysis}

Treatment and age of cheese caused significant differences $(P<0.05)$ in the levels of $\mathrm{pH} 4.6$-soluble $\mathrm{N}$ as a percentage of total $\mathrm{N}$ (Table 3). Cheese made with CC, irrespective of the amount of enzyme used during the manufacture, had significantly lower $(P<$ $0.05)$ levels of primary proteolysis throughout ripening and significantly lower compared with cheese made with BCC at all ripening times (Table 3, Figure 1b). This was due to the lower general proteolytic activity of CC compared with BCC (Kappeler et al., 2006). Camel chymosin has previously been shown to produce 
a)

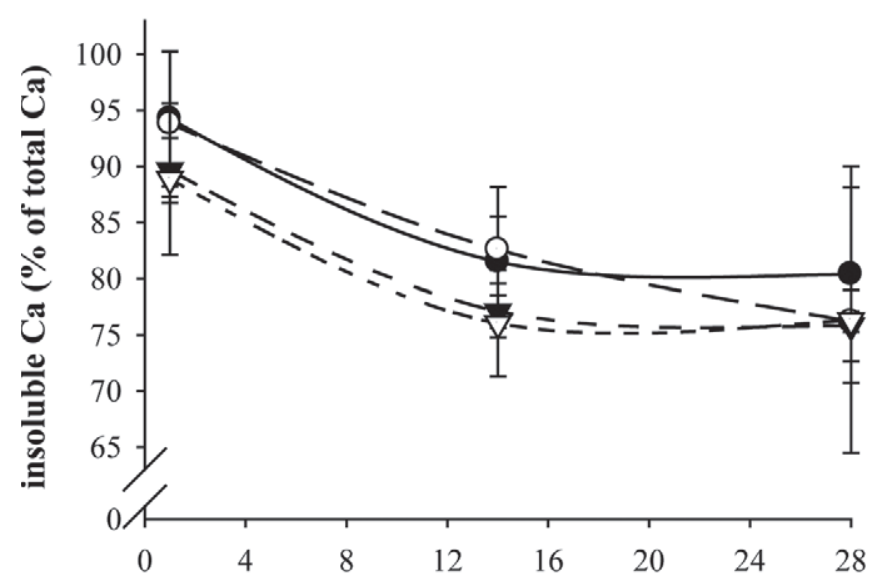

c)

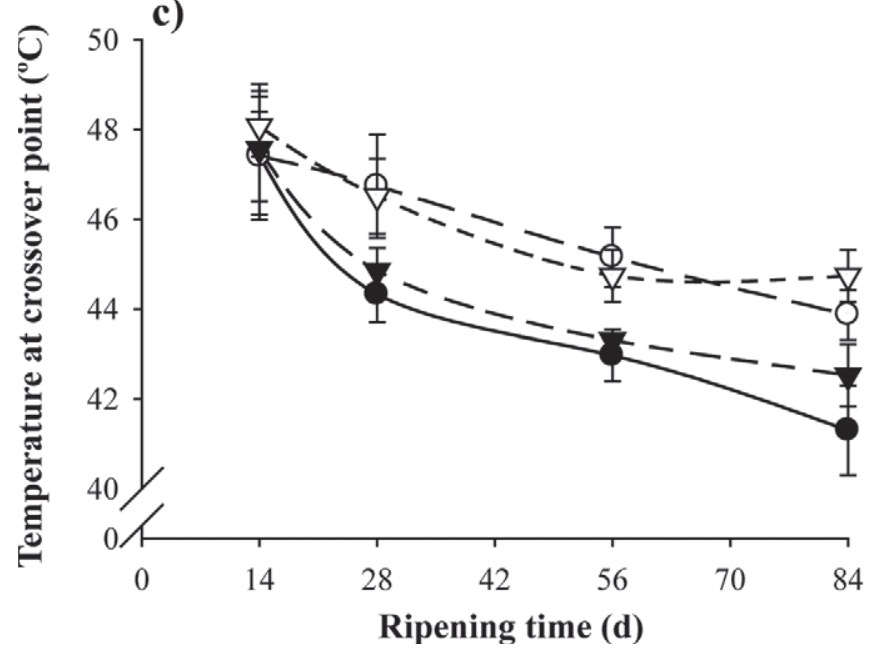

b)

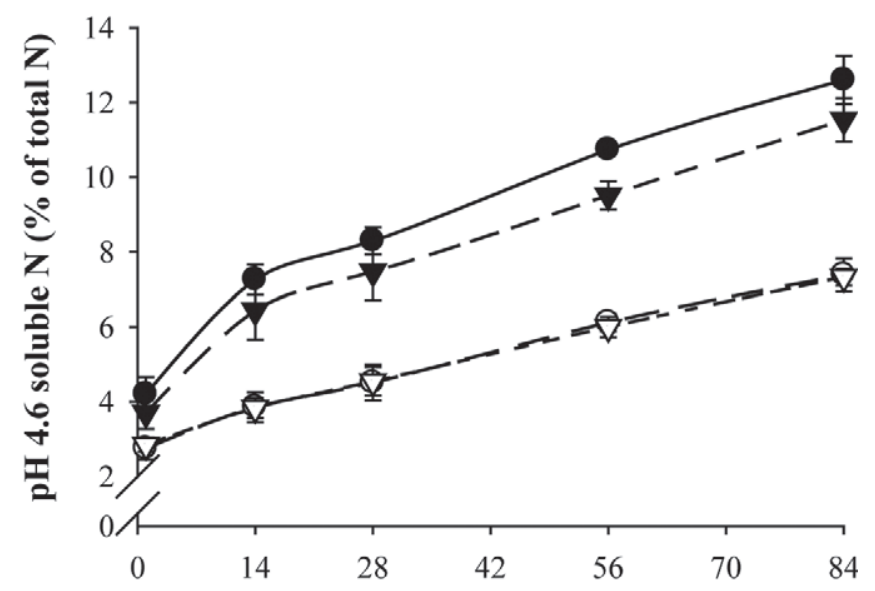

d)

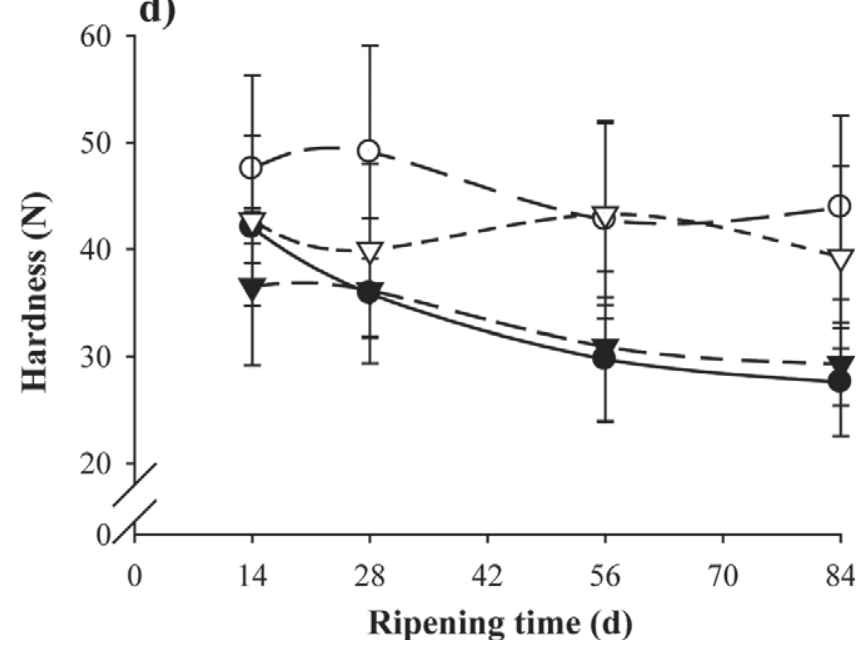

Figure 1. Changes in (a) percentage insoluble calcium as a percentage of total cheese Ca, (b) pH 4.6-soluble $\mathrm{N}$ as percentage of total $\mathrm{N}$, (c) temperature where the loss tangent $=1$ (crossover temperature), and (d) hardness values during ripening of low-moisture, part-skim Mozzarella made using high calf chymosin $(\mathrm{HBCC}, \bullet)$, low calf chymosin (LBCC, $\mathbf{v})$, high camel chymosin $(\mathrm{HCC}, \mathrm{O})$, or low camel chymosin (LCC, $\nabla)$. Values are means of 3 replicates; error bars indicate \pm 1 SD.

a lesser degree of proteolysis in cheese (Bansal et al., 2009; Govindasamy-Lucey et al., 2010; Grant 2011), although lower levels of $\mathrm{CC}$ were used in these prior studies. Proteolysis increased as ripening progressed for all cheeses, as expected. The amount of CC added during cheesemaking did not have a significant effect $(P>0.05)$ on the level of $\mathrm{pH} 4.6$-soluble $\mathrm{N}$, but the addition of higher levels of BCC (HBCC) produced a significantly $(P<0.05)$ higher level of proteolysis after 28 d compared with the LBCC cheese. Similarly, Dave et al. (2003) found that extent of overall proteolysis, as determined by $12 \%$ TCA-soluble $\mathrm{N}$ and the disappearance of intact caseins during storage, was proportional to the level of BCC used during the manufacture of directly acidified Mozzarella cheese. When higher concentrations of rennet are added to cheesemilk, it is expected that more coagulant would be retained in the curd, which could cause a higher level of proteolysis (Kindstedt et al., 1995). This trend was seen for BCC but not for CC.

\section{Rheological Properties of Cheese}

When the cheeses were heated, the $\mathrm{G}^{\prime}$ values decreased (results not shown). The LT values at temperatures $\leq 30^{\circ} \mathrm{C}$ remained constant during ripening with a value of approximately 0.3 ; at $\geq 30^{\circ} \mathrm{C}$, the $\mathrm{LT}$ increased to a maximum at approximately 60 to $65^{\circ} \mathrm{C}$ and then decreased (results not shown).

Treatment had a significant effect (Table 3 ) on the temperature where $\mathrm{LT}=1$ (the crossover point), which is the temperature where the cheese changes from a 
solid to viscous-like material (Gunasekaran and $\mathrm{Ak}$, 2003). No significant effect $(P>0.05)$ was observed between any of the treatments at $14 \mathrm{~d}$ of ripening but as ripening progressed the cheeses made with $\mathrm{CC}$ had significantly higher crossover points compared with the BCC-treated cheeses (Figure 1c; $P<0.05$ ). The decrease in the temperature where LT $=1$ during cheese ripening was in agreement with Govindasamy-Lucey et al. (2005) and Gunasekaran and Ak (2003). During ripening, we observed a slower rate of change in the temperature where $\mathrm{LT}=1$ for cheeses made with $\mathrm{CC}$ compared with those made with BCC (Figure 1c). The level of enzyme used for both types of coagulants during cheese manufacture did not seem to affect the crossover temperature. The crossover point is also considered the melt temperature (Gunasekaran and Ak, 2003). A reduction in the melt temperature during ripening is probably because of the loss of intact $\mathrm{CN}$ (caused by ongoing proteolysis) and the loss of cross-linking material (caused by the shift from insoluble to soluble calcium), both of which occur during cheese ripening (Lucey et al., 2003, 2005). As there was no difference in the INSOL calcium levels in all the cheeses (Figure 1a, Table 3), the higher crossover temperature for the cheeses manufactured with $\mathrm{CC}$ was due to the lower proteolysis in these cheeses compared with those made with BCC.

Treatment did not have a significant effect on the $\mathrm{LT}_{\max }$ value (Table 3). Govindasamy-Lucey et al. (2010) reported that the use of CC compared with BCC caused significantly lower melt in low-fat Cheddar cheese during ripening. Both proteolysis and INSOL calcium content play a role in changes in the rheological properties of cheese during ripening (Lucey et al., 2003). It has previously been reported that the INSOL calcium is more significantly correlated with the $\mathrm{LT}_{\max }$ than proteolysis (Lucey et al., 2005).

\section{Texture Profile Analysis}

Treatment had a significant effect on TPA hardness values (Table 3). Up to $56 \mathrm{~d}$ of ripening, TPA hardness did not differ significantly $(P>0.05)$ for any of the treatments, even though CC treatments were slightly higher in TPA hardness at $56 \mathrm{~d}$ (Figure 1d). As ripening time progressed, both $\mathrm{BCC}$ treatments decreased in hardness although HBCC or LBCC treatments did not differ throughout ripening $(P>0.05)$. The TPA hardness of CC-treated cheeses did not significantly $(P$ $>0.05)$ decrease during ripening and was essentially unchanged for both CC treatments (Figure 1d). At 84 $\mathrm{d}$ of ripening, cheeses made with $\mathrm{CC}$ were significantly $(P<0.05)$ harder. The observed decrease in the TPA hardness of the $\mathrm{HBCC}$ and $\mathrm{LBCC}$ cheeses over time was likely due to their higher proteolysis (Figure 1b, Table 3).

Low-moisture, part-skim Mozzarella made with BCC decreased in TPA hardness during ripening (Figure 1d; Kindstedt et al., 1995; Guinee et al., 2002), and this decrease in TPA hardness has been significantly correlated with a reduction in the level of intact casein (Guinee et al., 2002). Higher TPA hardness values for cheeses manufactured with $\mathrm{CC}$ could be due to the lower level of proteolysis in these cheeses (Figure 1b) as a result of the lower general proteolytic activity of the CC enzyme (Kappeler et al., 2006). In previous studies using CC in Cheddar cheeses, it was also found that cheeses made with $\mathrm{CC}$ were significantly harder than BCC cheeses by the end of the ripening period (Bansal et al., 2009; Govindasamy-Lucey et al., 2010; Grant, 2011). We observed no significant difference ( $P$ $>0.05$ ) between high and low CC treatments (Figure 1d). It might be expected that a higher concentration of CC would produce a cheese with lower TPA hardness values but we did not observe any significant difference in the proteolysis of the 2 types of CC cheeses. Kindstedt et al. (1995) found that the concentration of BCC used for cheesemaking did not affect the TPA hardness values of LMPS Mozzarella.

\section{Sensory Analysis: Unmelted Cheese}

Acidity and saltiness attributes of the unmelted cheeses were not significantly different between treatments $(P>0.05$; results not shown). Sensory firmness was significantly $(P<0.05)$ influenced by treatment (Table 4). At 14 and $28 \mathrm{~d}$ of ripening, $\mathrm{HBCC}$ and LBCC cheese had significantly lower firmness values than HCC cheese (Table 5). By 56 d of ripening, the $\mathrm{BCC}$ cheeses had significantly lower firmness than both cheeses made with CC. No significant differences were observed between enzyme levels, for each enzyme type, at any ripening point (Table 5). These results were in agreement with the TPA hardness results (Figure 1d), where cheese made with CC had higher TPA hardness at 56 and $84 \mathrm{~d}$ compared with BCC cheeses. The high sensory firmness values of $\mathrm{CC}$ changes during ripening are likely related to the lower degree of proteolysis and more intact casein levels in this cheese (Figure 1b).

Sensory adhesiveness of mass (defined as the degree to which the cheese sticks to the teeth or mouth after chewing) for unmelted cheese was significantly affected by treatment (Table 4 ). In cheeses aged up to $28 \mathrm{~d}$, no significant difference $(P>0.05)$ was observed for any treatment for adhesiveness of mass (Table 5). By $56 \mathrm{~d}$ of ripening, however, the CC-treated cheeses had significantly lower $(P<0.05)$ adhesiveness of mass than did the BCC cheeses. This could be due to the lower 
Table 4. Mean squares and probabilities (in parentheses), and $\mathrm{R}^{2}$ values for sensorial properties of unmelted low-moisture, part-skim Mozzarella cheese made with high calf chymosin (HBCC), low calf chymosin (LBCC), high camel chymosin (HCC), or low camel chymosin (LCC), and when cheeses were melted on pizzas in a forced-air commercial oven during the 84-d ripening period

\begin{tabular}{|c|c|c|c|c|c|c|c|c|}
\hline Factor $^{1}$ & df & \multicolumn{2}{|c|}{ Unmelted cheese } & \multicolumn{5}{|c|}{ Melted cheese } \\
\hline \multirow[t]{2}{*}{ Treatment $(\mathrm{T})$} & 3 & $9.41^{* *}$ & $6.33^{* *}$ & $18.1^{* *}$ & $19.9^{* *}$ & $3.89^{* *}$ & $3.86^{*}$ & $3.57^{*}$ \\
\hline & & (0.001) & (0.002) & $(<0.01)$ & $(<0.001)$ & $(<0.0001)$ & $(<0.01)$ & $(<0.01)$ \\
\hline Day of cheesemaking (D) & 2 & $\begin{array}{c}0.822 \\
(0.20)\end{array}$ & $\begin{array}{c}0.137 \\
(0.70)\end{array}$ & $\begin{array}{c}41.3^{* *} \\
(<0.01)\end{array}$ & $\begin{array}{c}2.40 \\
(0.08)\end{array}$ & $\begin{array}{c}0.699^{* *} \\
(<0.01)\end{array}$ & $\begin{array}{c}1.03 \\
(0.17)\end{array}$ & $\begin{array}{c}13.6^{* *} \\
(<0.001)\end{array}$ \\
\hline \multicolumn{9}{|l|}{ Subplot } \\
\hline Age (A) & 3 & $\begin{array}{l}4.68^{* *} \\
(00002)\end{array}$ & $\begin{array}{c}7.64^{* *} \\
-001)\end{array}$ & $14.2^{* *}$ & $22.9^{* *}$ & $3.93^{* *}$ & 0.301 & $23.7^{* *}$ \\
\hline $\mathrm{A} \times \mathrm{T}$ & 9 & $\begin{array}{l}0.294 \\
(0.78)\end{array}$ & $\begin{array}{c}0.802^{* *} \\
(0.004)\end{array}$ & $\begin{array}{c}(<0.0001) \\
1.20 \\
(0.37)\end{array}$ & $\begin{array}{c}(<0.0001) \\
0.542 \\
(0.53)\end{array}$ & $\begin{array}{c}(<0.0001) \\
0.206 \\
(0.19)\end{array}$ & $\begin{array}{c}(0.75) \\
0.229 \\
(0.96)\end{array}$ & $\begin{array}{c}<0.0001) \\
0.598 \\
(0.83)\end{array}$ \\
\hline Error & 24 & 0.489 & 0.169 & 1.05 & 0.595 & 0.133 & 0.729 & 1.11 \\
\hline $\mathrm{R}^{2}$ & & 0.81 & 0.93 & 0.89 & 0.91 & 0.89 & 0.52 & 0.81 \\
\hline
\end{tabular}

${ }^{1}$ Split-split plot design in which the 4 treatments (coagulant type and levels; HBCC, LBCC, HCC, LCC) were analyzed as a discontinuous variable and cheesemaking day was blocked (a $4 \times 3$ blocked design). Subplot included the effect of aging of cheese $(\mathrm{A})$, and age $\times$ treatment as variables.

$* 0.01<P \leq 0.05 ; * * P \leq 0.01$

proteolysis of $\mathrm{CC}$ cheeses giving them a more intact structure upon chewing. Low-moisture, part-skim Mozzarella made with BCC is known to be become more adhesive and sticky with age (Kindstedt et al., 1995; Chen et al., 2009).

\section{Sensory Analysis: Melted Cheese}

Melted cheese characteristics (surface, stretch, flavor, and textural) were evaluated by baking shredded LMPS Mozzarella on pizza crust (Table 1). Among the melted cheese surface characteristics that were evaluated, we observed no differences in the amount of free oil formed, blister color, or skinning among the cheeses (results not shown). Another melted cheese surface characteristic, blister quantity, was significantly $(P<0.05)$ affected by the type of treatment used and age (Table 4 ). When the cheeses aged, the quantity of blisters present on the melted cheese surface increased (Table 5). At $14 \mathrm{~d}$, we found no significant difference $(P>0.05)$ in the quantity of blisters for any of the melted cheeses (Table 5), but by $84 \mathrm{~d}$ of ripening, both $\mathrm{CC}$ treatments resulted in cheese that had significantly lower blister quantity.

Strand length and thickness are parameters used to analyze the stretch quality of cheese. Stretch is the ability of a protein network to maintain its integrity when an elongational stress is applied to cheese (Lucey et al., 2003). The level of intact casein affects cheese stretch and strand continuity; increased proteolysis can reduce stretch length and decrease strand thickness (Chen et al., 2009). Strand length (how far the cheese strand elongates before it breaks) was similar for all cheeses (results not shown). By 28 d of ripening, strand thickness was lower for BCC treatments than for CC treatments (Table 5). This was likely due to the higher levels of proteolysis in BCC treatments (Figure 1b). Oberg et al. (1992) found that when BCC, bovine pepsin, porcine pepsin, or Mucor miehei protease were used to manufacture Mozzarella cheese, cheeses made with porcine pepsin, which preferentially degraded $\beta$-CN, had the most stretch compared with the other coagulants tested.

We observed no significant differences in the flavor attributes (acid and salt intensities) of the melted cheeses (results not shown). Melted textural characteristics, hardness, chewiness, and cohesiveness of mass were significantly $(P<0.05)$ influenced by the treatment used (Table 4). Melt hardness, which is the force required to bite through the melted cheeses using the molar, decreased with age for the BCC cheeses (Table $5)$. The HBCC treatment had the lowest melt hardness values throughout ripening, and at $28 \mathrm{~d}$ of ripening this became significantly different $(P<0.05)$ compared with all other treatments (Table 5). At 56 and $84 \mathrm{~d}$ of ripening, both $\mathrm{BCC}$ treatments had significantly $(P<$ $0.05)$ lower melt hardness values compared with the CC treatments. These results were similar to those found for the sensory firmness of unmelted cheese and TPA hardness (Figure 1d).

Chewiness of melted cheese was similar in all cheeses during the first $28 \mathrm{~d}$ of ripening (Table 5). By $56 \mathrm{~d}$ of ripening, cheeses manufactured with BCC were less chewy compared with cheeses made with CC. Melt cohesiveness of mass, which evaluates the degree to which a melted cheese sample holds together or adheres to itself after chewing, increased during ripening 
Table 5. Sensory analysis results of unmelted low-moisture, part-skim Mozzarella cheese made with high calf chymosin (BHCC), low calf chymosin (LBCC), high camel chymosin (HCC), or low camel chymosin (LCC), and when the cheeses were melted on pizzas in a forced-air commercial oven during the 84-d ripening period

\begin{tabular}{|c|c|c|c|c|c|}
\hline \multirow[b]{2}{*}{ Attribute } & \multirow{2}{*}{$\begin{array}{l}\text { Ripening } \\
\text { time (d) }\end{array}$} & \multicolumn{4}{|c|}{ Treatment } \\
\hline & & $\mathrm{HBCC}$ & $\mathrm{LBCC}$ & $\mathrm{HCC}$ & LCC \\
\hline \multicolumn{6}{|l|}{ Unmelted cheese } \\
\hline \multirow{4}{*}{ Firmness } & 14 & $7.65^{\mathrm{b}, \mathrm{A}}$ & $7.63^{\mathrm{b}, \mathrm{A}}$ & $8.91^{\mathrm{a}, \mathrm{A}}$ & $8.48^{\mathrm{a}, \mathrm{A}}$ \\
\hline & 28 & $6.70^{\mathrm{c}, \mathrm{AB}}$ & $6.98^{\mathrm{bc}, \mathrm{AB}}$ & $8.21^{\mathrm{a}, \mathrm{A}}$ & $7.90^{\mathrm{ba}, \mathrm{A}}$ \\
\hline & 56 & $5.96^{\mathrm{b}, \mathrm{B}}$ & $5.56^{\mathrm{b}, \mathrm{B}}$ & $7.92^{\mathrm{a}, \mathrm{A}}$ & $7.37^{\mathrm{a}, \mathrm{A}}$ \\
\hline & 84 & $7.07^{\mathrm{b}, \mathrm{AB}}$ & $6.63^{\mathrm{b}, \mathrm{AB}}$ & $8.70^{\mathrm{a}, \mathrm{A}}$ & $8.81^{\mathrm{a}, \mathrm{A}}$ \\
\hline \multirow[t]{4}{*}{ Adhesiveness of mass } & 14 & $4.17^{\mathrm{a}, \mathrm{B}}$ & $3.58^{\mathrm{a}, \mathrm{B}}$ & $3.42^{\mathrm{a}, \mathrm{B}}$ & $3.62^{\mathrm{a}, \mathrm{B}}$ \\
\hline & 28 & $4.42^{\mathrm{a}, \mathrm{B}}$ & $4.55^{\mathrm{a}, \mathrm{B}}$ & $3.62^{\mathrm{a}, \mathrm{AB}}$ & $3.95^{\mathrm{a}, \mathrm{A}}$ \\
\hline & 56 & $5.78^{\mathrm{a}, \mathrm{A}}$ & $6.13^{\mathrm{a}, \mathrm{A}}$ & $3.86^{\mathrm{b}, \mathrm{AB}}$ & $3.95^{\mathrm{b}, \mathrm{A}}$ \\
\hline & 84 & $6.46^{\mathrm{a}, \mathrm{A}}$ & $6.39^{\mathrm{a}, \mathrm{A}}$ & $4.47^{\mathrm{b}, \mathrm{A}}$ & $4.60^{\mathrm{b}, \mathrm{A}}$ \\
\hline \multicolumn{6}{|l|}{ Melted cheese } \\
\hline \multirow[t]{4}{*}{ Blister quantity } & 14 & $8.77^{\mathrm{a}, \mathrm{B}}$ & $8.73^{\mathrm{a}, \mathrm{B}}$ & $7.55^{\mathrm{b}, \mathrm{B}}$ & $6.59^{\mathrm{b}, \mathrm{BC}}$ \\
\hline & 28 & $10.28^{\mathrm{a}, \mathrm{AB}}$ & $9.55^{\mathrm{ba}, \mathrm{AB}}$ & $8.08^{\mathrm{ba}, \mathrm{AB}}$ & $6.10^{\mathrm{b}, \mathrm{C}}$ \\
\hline & 56 & $9.30^{\mathrm{a}, \mathrm{AB}}$ & $10.34^{\mathrm{a}, \mathrm{AB}}$ & $8.69^{\mathrm{a}, \mathrm{AB}}$ & $8.41^{\mathrm{a}, \mathrm{AB}}$ \\
\hline & 84 & $11.75^{\mathrm{a}, \mathrm{A}}$ & $11.59^{\mathrm{a}, \mathrm{B}}$ & $9.16^{\mathrm{b}, \mathrm{A}}$ & $9.27^{\mathrm{b}, \mathrm{A}}$ \\
\hline \multirow[t]{4}{*}{ Strand thickness } & 14 & $4.96^{\mathrm{a}, \mathrm{A}}$ & $5.63^{\mathrm{a}, \mathrm{A}}$ & $6.93^{\mathrm{a}, \mathrm{A}}$ & $6.40^{\mathrm{a}, \mathrm{A}}$ \\
\hline & 28 & $3.98^{\mathrm{b}, \mathrm{B}}$ & $5.00^{\mathrm{b}, \mathrm{AB}}$ & $7.26^{\mathrm{a}, \mathrm{A}}$ & $7.20^{\mathrm{a}, \mathrm{A}}$ \\
\hline & 56 & $2.86^{\mathrm{b}, \mathrm{C}}$ & $3.43^{\mathrm{b}, \mathrm{BC}}$ & $5.44^{\mathrm{a}, \mathrm{AB}}$ & $6.05^{\mathrm{a}, \mathrm{A}}$ \\
\hline & 84 & $1.88^{\mathrm{b}, \mathrm{D}}$ & $2.17^{\mathrm{b}, \mathrm{C}}$ & $4.11^{\mathrm{a}, \mathrm{B}}$ & $4.01^{\mathrm{a}, \mathrm{B}}$ \\
\hline \multirow{4}{*}{ Melt hardness } & 14 & $3.91^{\mathrm{c}, \mathrm{A}}$ & $4.19^{\mathrm{bc}, \mathrm{A}}$ & $4.62^{\mathrm{a}, \mathrm{A}}$ & $4.39^{\mathrm{ba}, \mathrm{A}}$ \\
\hline & 28 & $3.33^{\mathrm{b}, \mathrm{AB}}$ & $4.05^{\mathrm{a}, \mathrm{A}}$ & $4.53^{\mathrm{a}, \mathrm{A}}$ & $4.48^{\mathrm{a}, \mathrm{A}}$ \\
\hline & 56 & $2.64^{\mathrm{b}, \mathrm{B}}$ & $3.02^{\mathrm{b}, \mathrm{B}}$ & $4.15^{\mathrm{a}, \mathrm{A}}$ & $4.04^{\mathrm{a}, \mathrm{A}}$ \\
\hline & 84 & $2.37^{\mathrm{b}, \mathrm{B}}$ & $2.44^{\mathrm{b}, \mathrm{B}}$ & $3.57^{\mathrm{a}, \mathrm{A}}$ & $3.77^{\mathrm{a}, \mathrm{A}}$ \\
\hline \multirow[t]{4}{*}{ Melt chewiness } & 14 & $7.40^{\mathrm{a}, \mathrm{A}}$ & $7.69^{\mathrm{a}, \mathrm{A}}$ & $8.18^{\mathrm{a}, \mathrm{A}}$ & $8.20^{\mathrm{a}, \mathrm{A}}$ \\
\hline & 28 & $7.71^{\mathrm{a}, \mathrm{A}}$ & $7.74^{\mathrm{a}, \mathrm{A}}$ & $8.38^{\mathrm{a}, \mathrm{A}}$ & $8.46^{\mathrm{a}, \mathrm{A}}$ \\
\hline & 56 & $7.37^{\mathrm{b}, \mathrm{A}}$ & $7.84^{\mathrm{b}, \mathrm{A}}$ & $8.86^{\mathrm{a}, \mathrm{A}}$ & $8.94^{\mathrm{a}, \mathrm{A}}$ \\
\hline & 84 & $7.22^{\mathrm{b}, \mathrm{A}}$ & $7.81^{\mathrm{b}, \mathrm{A}}$ & $8.13^{\mathrm{ba}, \mathrm{A}}$ & $9.08^{\mathrm{a}, \mathrm{A}}$ \\
\hline \multirow{4}{*}{$\begin{array}{l}\text { Melt cohesiveness of } \\
\text { mass }\end{array}$} & 14 & $8.93^{\mathrm{a}, \mathrm{B}}$ & $7.80^{\mathrm{b}, \mathrm{B}}$ & $8.03^{\mathrm{b}, \mathrm{AB}}$ & $7.75^{\mathrm{b}, \mathrm{B}}$ \\
\hline & 28 & $10.66^{\mathrm{a}, \mathrm{AB}}$ & $9.13^{\mathrm{b}, \mathrm{AB}}$ & $8.35^{\mathrm{b}, \mathrm{B}}$ & $8.51^{\mathrm{b}, \mathrm{AB}}$ \\
\hline & 56 & $10.75^{\mathrm{a}, \mathrm{AB}}$ & $10.36^{\mathrm{a}, \mathrm{A}}$ & $10.31^{\mathrm{a}, \mathrm{AB}}$ & $9.47^{\mathrm{a}, \mathrm{AB}}$ \\
\hline & 84 & $11.75^{\mathrm{a}, \mathrm{A}}$ & $11.23^{\mathrm{a}, \mathrm{A}}$ & $11.08^{\mathrm{a}, \mathrm{A}}$ & $11.53^{\mathrm{a}, \mathrm{A}}$ \\
\hline
\end{tabular}

${ }^{\mathrm{a}-\mathrm{c}}$ Means within the same row not sharing a common lowercase superscript differ $(P<0.05$; comparing the effect of treatment at a single ripening time).

${ }^{\mathrm{A}-\mathrm{C}}$ Means within the same column (for a particular attribute) not sharing a common uppercase superscript differ $(P<0.05$; comparing the effect of ripening time for a single treatment).

${ }^{1}$ Values represent the means of 3 replicate trials $(n=3)$; the Fisher protected least significant difference test was used to compare means.

(Table 5). Melt cohesiveness generally increases with age for LMPS cheese (Chen et al., 2009). During the first $28 \mathrm{~d}$ of ripening, the melt cohesiveness of mass was significantly $(P<0.05)$ higher for HBCC cheeses than for LBCC or the cheeses made with CC (Table 5). However, by $56 \mathrm{~d}$ of ripening, we detected no significant difference $(P>0.05)$ between coagulant treatments.

\section{CONCLUSIONS}

Cheeses manufactured with CC had a lower level of proteolysis compared with $\mathrm{BCC}$ throughout ripening. Because all cheeses had similar moisture contents, $\mathrm{pH}$ values, and INSOL Ca levels, the lesser degree of proteolysis in CC cheeses can explain its firmer and chewier texture. Shredding and slicing of LMPS Mozzarella requires a firm, nonadhesive cheese texture. Sensory texture descriptive analyses and instrumental texture profile analyses indicated that cheeses manufactured with CC were firmer and less sticky during ripening than those made with BCC. This suggests that the acceptable machinability window (for shredding and slicing) of LMPS Mozzarella could be extended with the use of CC. Cheese performance on pizza (i.e., properties such as blister quantity, strand thickness, melt hardness, and melt chewiness) was maintained for a longer storage time in $\mathrm{CC}$ cheeses than in cheeses made with BCC. Thus, CC can be used for the manufacture of LMPS Mozzarella to extend shelf-life performance. Higher crossover temperatures indicated that CC cheeses retained their melt characteristics for a longer period than did BCC cheeses. In this current study, the Mozzarella cheeses were stored at $3^{\circ} \mathrm{C}$, whereas in retail stores, Mozzarella cheeses are often stored at temperatures between 6 and $10^{\circ} \mathrm{C}$ for a few weeks before sale. Increased storage temperature (from $3{ }^{\circ} \mathrm{C}$ to $6-10^{\circ} \mathrm{C}$ ) will likely promote greater proteolysis and thus further reduce the acceptable window of retail and 
home-use shelf-life. Therefore, the use of CC during the manufacture would help to extend the retail or the home use shelf-life.

\section{ACKNOWLEDGMENTS}

The authors gratefully acknowledge the support of a travel bursary from the Fulbright Commission of Ireland. The authors thank personnel from Wisconsin Center for Dairy Research and University of Wisconsin Dairy Plant (Madison, WI) for their assistance and support in cheesemaking, analytical work, and sensory analysis. The financial support of the Wisconsin Center for Dairy Research Industry Team; Wisconsin Milk Marketing Board (Madison, WI) is greatly appreciated. We also thank Cargill Texturizing Solutions. (Waukesha, WI) and Chr. Hansen Inc. (Milwaukee, WI) for their donation of the starter cultures and coagulants, respectively, used in this study.

\section{REFERENCES}

Alvarez, R. J. 1986. Expectations of Italian cheese in the pizza industry. Page 130-138 in Proc. 23rd Annu. Marschall Invit. Italian Cheese Conf., Marschall Products-Miles Laboratories Inc., Madison, WI.

AOAC International. 2000. Official Methods of Analysis. Vol. 1. 17th ed. AOAC International, Arlington, VA.

Bansal, N., M. A. Drake, P. Piraino, M. L. Broe, M. Harboe, P. F. Fox, and P. L. H. McSweeney. 2009. Suitability of recombinant camel (Camelus dromedarius) chymosin as a coagulant for Cheddar cheese. Int. Dairy J. 19:510-517.

Bourne, M. C. 1978. Texture profile analysis. Food Technol. 32:62-66 72.

Chen, C., D. Wolle, and D. Sommer. 2009. Mozzarella. Pages 459-487 in The Sensory Evaluation of Dairy Products, 2nd ed. Springer Science and Business Media, New York, NY.

Creamer, L. K. 1976. Casein proteolysis in Mozzarella-type cheese. N.Z. J. Dairy Sci. Technol. 11:130-131.

Dave, R. I., D. J. McMahon, C. Oberg, and J. R. Broadbent. 2003. Influence of coagulant level on proteolysis and functionality of Mozzarella cheeses made using direct acidification. J. Dairy Sci. $86: 114-126$.

De Jong, L. 1976. Protein breakdown in soft cheese and its relation to consistency. I. Proteolysis and consistency of "Noordhollanse Meshanger" cheese. Neth. Milk Dairy J. 30:242-253.

Farkye, N. Y., L. J. Kiely, R. D. Allhouse, and P. S. Kindstedt. 1991. Proteolysis in Mozzarella cheese during refrigerated storage. J. Dairy Sci. 74:1433-1438.

Govindasamy-Lucey, S., J. J. Jaeggi, A. L. Bostley, M. E. Johnson, and J. A. Lucey. 2004. Standardization of milk using cold ultrafiltration retentates for the manufacture of Parmesan cheese. J. Dairy Sci. 87:2789-2799.

Govindasamy-Lucey, S., J. J. Jaeggi, M. E. Johnson, T. Wang, and J. A. Lucey. 2005. Use of cold ultrafiltered retentates for standardization of milks for pizza cheese: Impact on yield and functionality. Int. Dairy J. 15:941-955.

Govindasamy-Lucey, S., Y. Lu, J. J. Jaeggi, M. E. Johnson, and J. A. Lucey. 2010. Impact of camel chymosin on the textural and sensory properties of low-fat Cheddar cheese. Aust. J. Dairy Technol. 65:139-142.

Grant, K. 2011. The impact of sodium chloride reduction on the compositional, functional, and flavor properties of full-fat Cheddar cheese. MS Thesis. University of Wisconsin-Madison, Madison.
Guinee, T. P., E. P. Feeney, M. A. E. Auty, and P. F. Fox. 2002. Effect of $\mathrm{pH}$ and calcium concentration on some textural and functional properties of Mozzarella cheese. J. Dairy Sci. 85:1655-1669.

Gunasekaran, S., and M. M. Ak. 2003. Cheese Rheology and Texture. CRC Press LLC, Boca Raton, FL.

Hassan, A., M. E. Johnson, and J. A. Lucey. 2004. Changes in the proportions of soluble and insoluble calcium during the ripening of Cheddar cheese. J. Dairy Sci. 87:854-862.

Johnson, M. E., and J. A. Lucey. 2006. Calcium: A key factor in controlling cheese functionality. Aust. J. Dairy Technol. 61:77-83.

Johnson, M. E., and N. F. Olson. 1985. A comparison of available methods for determining salt levels in cheese. J. Dairy Sci. 68:1020-1024.

Kappeler, S. R., H. M. van den Brink, H. Rahbek-Neilsen, Z. Farah, Z. Puhan, E. B. Hansen, and E. Johansen. 2006. Characterization of recombinant camel chymosin reveals superior properties for the coagulation of bovine and camel milk. Biochem. Biophys. Res. Commun. 342:647-654.

Kindstedt, P., M. Carić, and S. Milanović. 2004. Pasta-filata cheeses. Pages 251-277 in Cheese: Chemistry, Physics and Microbiology. Vol. 2. 3rd ed. P. F. Fox, P. L. H. McSweeney, T. M. Cogan, and T. P. Guinee, ed. Elsevier Ltd., London, UK.

Kindstedt, P. S., J. J. Yun, D. M. Barbano, and K. L. Larose. 1995. Mozzarella cheese: Impact of coagulant concentration on chemical composition, proteolysis, and functional properties. J. Dairy Sci. 78:2591-2597.

Kuchroo, C. N., and P. F. Fox. 1982. Soluble nitrogen in Cheddar cheese: Comparison of extraction procedures. Milchwissenschaft 37:331-335

Lee, M.-R., M. E. Johnson, and J. A. Lucey. 2005. Impact of modifications in acid development on the insoluble calcium content and rheological properties of Cheddar cheese. J. Dairy Sci. 88:37983809 .

Lucey, J. A., M. E. Johnson, and D. S. Horne. 2003. Perspectives on the basis of the rheology and texture properties of cheese. J. Dairy Sci. 86:2725-2743.

Lucey, J. A., R. Mishra, A. Hassan, and M. E. Johnson. 2005. Rheological and calcium changes during the ripening of Cheddar cheese. Int. Dairy J. 15:645-653.

Madkor, S., P. F. Fox, S. I. Shalabi, and N. H. Metwalli. 1987. Studies on the ripening of Stilton cheese: Proteolysis. J. Food Chem. $25: 13-29$.

Marshall, R. T. 1992. Standard Methods for the Examination of Dairy Products. 16th ed. American Public Health Association, Washington, DC.

Meilgaard, M. M., G. V. Civille, and B. T. Carr. 1999. Selection and training of panel members. Pages 174-176 in Sensory Evaluation Techniques. 3rd ed. CRC Press, Boca Raton, FL.

Oberg, C. J., R. K. Merrill, R. J. Brown, and G. H. Richardson. 1992. Effects of milk-clotting enzymes on physical properties of Mozzarella cheese. J. Dairy Sci. 75:669-675.

Oberg, C. J., R. K. Merrill, L. V. Moyes, R. J. Brown, and G. H. Richardson. 1991a. Effects of Lactobacillus helveticus culture on the physical properties of Mozzarella cheese. J. Dairy Sci. 74:41014107.

Oberg, C. J., A. Wang, L. V. Moyes, R. J. Brown, and G. H. Richardson. 1991b. Effects of proteolytic activity of thermolactic cultures on physical properties of Mozzarella cheese. J. Dairy Sci. 74:389-397.

Park, Y. W. 2000. Comparison of mineral and cholesterol composition of different commercial goat milk products manufactured in USA. Small Rumin. Res. 37:115-124.

SAS Institute. 2002-2003. SAS User's Guide: Statistics. Version 9.1. SAS Institute Inc., Cary, NC.

Sheehan, J. J., K. O'Sullivan, and T. P. Guinee. 2004. Effect of coagulant type and storage temperature on the functionality of reducedfat Mozzarella cheese. Lait 84:551-566.

Tunick, M. H., K. L. Mackey, J. J. Shieh, P. W. Smith, P. Cooke, and E. L. Malin. 1993. Rheology and microstructure of low-fat Mozzarella cheese. Int. Dairy J. 3:649-662. 